\title{
Morphological and nomenclatural notes on some Scathophagidae (Diptera)
}

\author{
Заметки по морфологии и номенклатуре в семействе \\ Scathophagidae (Diptera)
}

\author{
A.L. Ozerov \\ A. $\Lambda$. Озеров \\ Zoological Museum, Lomonosov Moscow State University, Bol'shaya Nikitskaya 2, Moscow 125009, Russia. \\ E-mail: ozerov2455@rambler.ru \\ Зоологический музей, МГУ им. М.В. Ломоносова, Большая Никитская ул., 2, Москва 125009, Россия.
}

KEY WORDS: Diptera, Scathophagidae, Bostrichopyga crassipes (Zetterstedt, 1838), female, description, new synonyms.

КЛЮЧЕВЫЕ СЛОВА: Diptera, Scathophagidae, Bostrichopyga crassipes (Zetterstedt, 1838), самка, описание, новый синоним.

ABSTRACT. Description of female of Bostrichopyga crassipes (Zetterstedt, 1838) is given for the first time, with illustrations of female ovipositor. Two new synonyms are proposed: Acanthocnema sternalis Suwa, 1986 = Acanthocnema vikhrevi Ozerov et Krivosheina, 2014, syn.n.; Scathophaga intermedia (Walker, 1849) = Scathophaga hadleyi Ozerov, 2013, syn.n.

РЕЗЮМЕ. Впервые дано описание самки Bostrichopyga crassipes (Zetterstedt, 1838), приведены иллюстрации яйцеклада. Установлены 2 новых синонима: Acanthocnema sternalis Suwa, $1986=$ Acanthocnema vikhrevi Ozerov et Krivosheina, 2014, syn.n.; Scathophaga intermedia (Walker, 1849) = Scathophaga hadleyi Ozerov, 2013, syn.n.

\section{Morphological part}

Bostrichopyga crassipes (Zetterstedt, 1838) Figs 1-3.

The genus Bostrichopyga was described by Becker [1894] and primarily included only one species in the World - Bostrichopyga crassipes (Zetterstedt, 1838). The second species, Bostrichopyga borealis Hendel, 1903, was described by Hendel [1903] from Norway on a single male specimen and after that no specimens were found. Ozerov and Krivosheina [2014a], studying the holotype of $B$. borealis, discovered that this specimen is conspecific of B.crassipes. Now the genus Bostrichopyga is monotypic with the only species B. crassipes.

Bostrichopyga crassipes was registered in Sweden and Finland [Hackman, 1956], also in Norway [Hen- del, 1903 (as Bostrichopyga borealis)]. Gorodkov [1970] mentioned this species for Russia from Kola Peninsula and Yakutia (Verchoyansk), but without specifying the material. Later, in Catalogue of Palaearctic Diptera, Gorodkov noted this species from the European territory of Russia only [Gorodkov, 1986]. Ozerov \& Krivosheina [2014a] did not point this species for Russia because the material mentioned by Gorodkov [1970] seemed to be absent in the collection of the Zoological Institute, St.-Petersburg (ZISP). However during the repeated revision of the ZISP collection in 2018 the specimens of B. crassipes from Yakutia (Verchoyansk) were found as well as several specimens from Altay (see below).

$B$. crassipes was known from male specimens only till now; male of $B$. crassipes was fully described and illustrated by Ozerov \& Krivosheina [2014a]. The female of B. crassipes was unknown. I discovered female among Altay material. Its description is given below for the first time.

MATERIAL. RUSSIA: Altay, Kosh-Agach $\left(49.9975^{\circ} \mathrm{N}\right.$

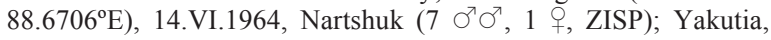
Verchoyansk $\left(67.5483^{\circ} \mathrm{N} 133.3961^{\circ} \mathrm{E}\right), 15$. VI.1913, Mikhailov (2 $\left.\mathrm{O}^{7} \mathrm{O}^{\top}, \mathrm{ZISP}\right)$.

DESCRIPTION. Female. Length of body $7.6 \mathrm{~mm}$. Length of wing $6.2 \mathrm{~mm}$. All setae and hairs on head and thorax yellowish.

Head. Fronal vitta black in upper quarter and yellow in lower part, matt. Fronto-orbital plate and ocellar triangle black, greyish dusted. Parafacial, face and gena yellow, whitish dusted. Postcranium black, greyish dusted, covered with setae and hairs. Setae: $2-3$ orbitals, 2 frontals, 1 ocellar , 1 postocellar (weak, convergent), 1 inner vertical, 1 outer vertical; 2 pairs of strong vibrissae and several pairs of short subvibrissae present.

How to cite this article: Ozerov A.L. 2019. Morphological and nomenclatural notes on some Scathophagidae (Diptera) // Russian Entomol. J. Vol.28. No.3. P.328-330. doi: 10.15298/rusentj.28.3.13 

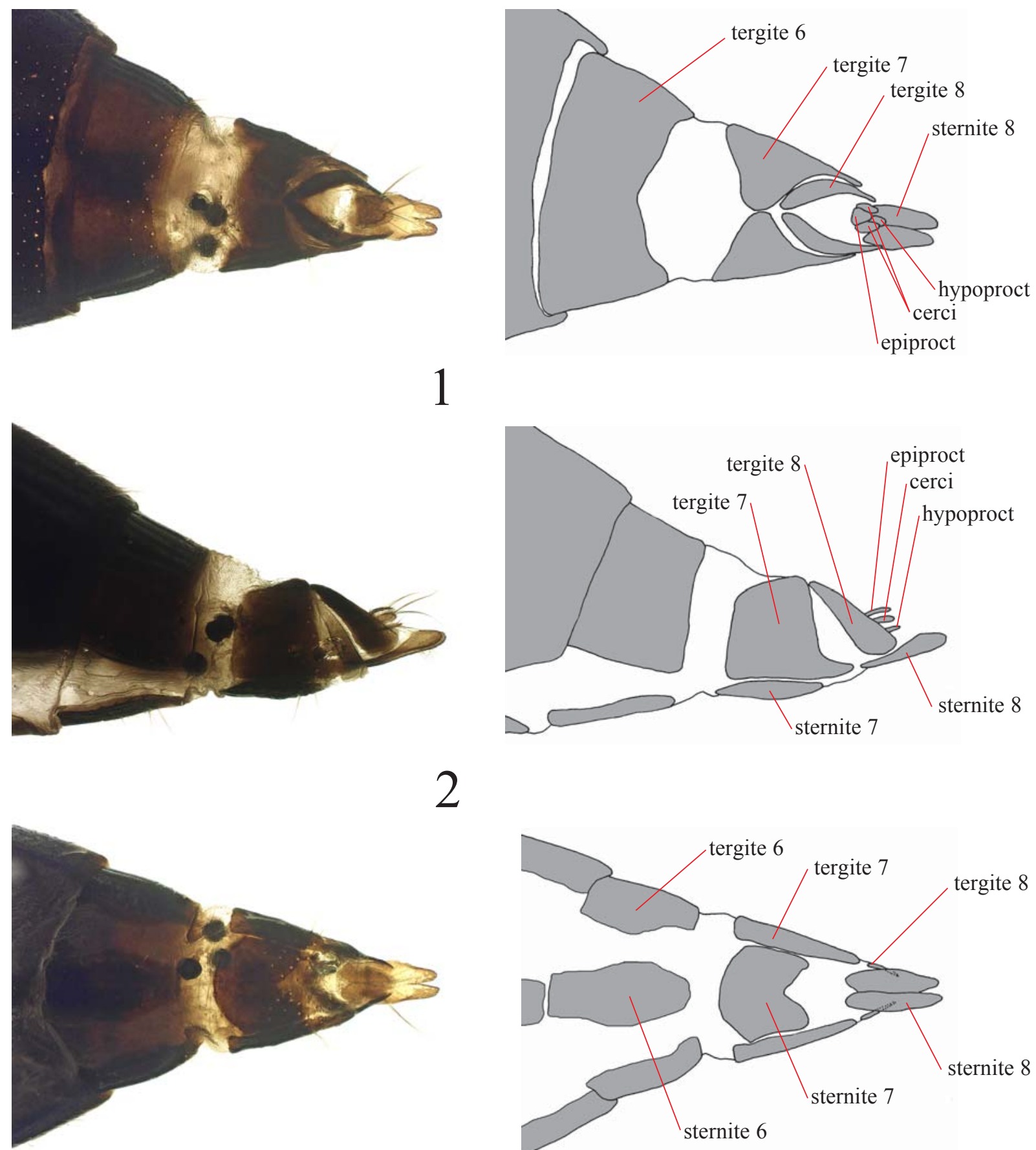

2

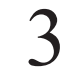

Figs 1-3. Bostrichopyga crassipes (Zetterstedt), end of female abdomen: 1 - dorsal view; 2 - lateral view; 3 - ventral view. Рис. 1-3. Bostrichopyga crassipes (Zetterstedt), конец брюшка самки: 1 - сверху; 2 - сбоку; 3 - снизу.

Antenna black, postpedicel rounded apically, approximately 1.5 times as long as wide. Arista bare. Palpus yellow, distinctly spatulate. Clypeus and proboscis black.

Thorax black, densely grey dusted. Scutum with following setae: 2 postpronotals, 2 notopleurals, $1+1$ intra-alars, 1+1 supra-alars, 2 postalars, and $2+3$ dorsocentrals; acrostichal setulae short, in two rows. Proepisternum and proepimeron with several hairs. Anepisternum covered with hairs in posterior half and with a row of setae along posterior margin. Katepisternum with one strong seta in posterodorsal 
corner. Anepimeron bare or with one setula at middle. Scutellum greyish dusted, with a pair of strong basal scutellar and a pair of strong apical scutellar setae.

Legs yellow, only mid and hind coxae, also hind trochanter blackish. Fore femur simple, with rows of thin posterovental and dorsal/posterodorsal setae. Fore tibia with irregular rows of small setae ventrally, with 1 long dorsal seta at middle, also with 1 preapical dorsal and 1 apical posterior setae. Mid femur with 1 preapical posterodorsal seta. Mid tibia with 1 anterodorsal and 1 posterodorsal setae at middle, and a ring of apical setae. Hind femur with a row of anterodorsal setae and 4-5 anteroventral setae in apical half. Hind tibia with 2 anterodorsal, 1 dorsal/posterodorsal, 1 preapical dorsal, and apical anteroventral setae.

Wing tinged with brownish, veins blackish. Vein $\mathrm{R}$ bare. Calypteres, including margins, and halteres yellowish.

Abdomen black, subshining, covered with hairs. Syntergite $1+2$ with several setulae at sides.

Ovipositor (Figs 1-3) short and compact, more or less cylindrical. Tergite 7 is divided medially into two sclerites. Sternite 7 relatively large, rounded antreiorly with posterior excision (Fig. 3). Tergite 8 is represented by two narrow separated sclerites (Fig. 1). Sternite 8 like two long plates (Fig. 3). Proctiger shifted on dorsal side and formed by entire epiproct, pair of cerci, and hypoproct. Epiproct, cerci, and hypoproct with long setae pointing upward and backwards.

DISTRIBUTION. Palaearctic. - Europe: Finland, Norway, Sweden; Asia: Russia (Altai, Yakutia).

\section{Nomenclatural part}

\section{Acanthocnema sternalis Suwa, 1986}

sternalis Suwa, 1986: 14 (Acanthocnema). Type-locality: Mt. Daisetsu (Japan, Hokkaidô).

vikhrevi Ozerov et Krivosheina, 2014b: 204 (Acanthocnema). Type-locality: Yablonevyy Pass $\left(60.59^{\circ} \mathrm{N} 151.53^{\circ} \mathrm{E}\right)$ (Russia, Magadan Oblast) - syn.n.

During the description [Ozerov, Krivosheina, $2014 \mathrm{~b}$ ] and in the review of the species of the genus Acanthocnema of Russia [Ozerov, Krivosheina, 2018] it was asserted that $A$. vikhrevi is closely related to $A$. sternalis by the structure of male terminalia and distinguished from it by several characters of external morphology. For example $A$. vikhrevi easily differs from $A$. sternalis by the presence of preapical anterodorsal seta on mid tibia. Later I noticed that Suwa paid no attention to this character in other species also [Suwa, 1986].
Herewith, I consider $A$. vikhrevi as a junior synonym of A. sternalis.

\section{Scathophaga intermedia (Walker, 1849)}

intermedia Walker, 1849: 980 (Scatophaga). Type-locality: "Nova Scotia" (Canada).

hadleyi Ozerov, 2013: 88 (Scathophaga). Type-locality: Tserkovnaya Bay $\left(43.75^{\circ} \mathrm{N} 146.70^{\circ} \mathrm{E}\right)$, Shikotan I. (Russia, Sakhalin Oblast) - syn.n.

During the additional study of the holotype of $S$. hadleyi and comparison with the males of Scathophaga intermedia it was discovered that the species are conspecific. Sternite 5 of the male of $S$. hadleyi looks elongated [Ozerov, 2013, Fig. 31] because its margings proved to be folded. Herewith, I consider hadleyi as a junior synonym of $S$. intermedia.

Acknowledgement. The investigation was fulfilled within the state project No AAAA-A16-116021660077-3.

\section{References}

Becker T. 1894. Dipterologische Studien. I. Scatomyzidae // Berliner Entomologische Zeitschrift. Bd.39. H.1. S.77-196.

Gorodkov K.B. 1970. [Family Scathophagidae (Cordyluridae, Scatomyzidae, Scopeumatidae)] // Bei-Bienko G.Ya. (ed.). Key to the insects of the European part of the USSR. Vol.V. Diptera, Siphonaptera. Part 2. P.440-458 [in Russian].

Gorodkov K.B. 1986. Family Scathophagidae // Soós Á, Papp L. (eds.). Catalogue of Palaearctic Diptera. Vol. 11. Scathophagidae-Hypodermatidae. Akadémiai Kiadó, Budapest. P.11-41.

Hackman W. 1956. The Scatophagidae (Dipt.) of Eastern Fennoscandia // Societas pro Fauna et Flora Fennica. Fauna fennica II. Helsingforsiae. 67 pp.

Hendel F. 1903. Drei neue boreale Musidae acalyptratae // Verhandlungen der kaiserlich-königlichen zoologisch-botanischen Gesellschaft in Wien. Bd.53. S.383-385.

Ozerov A.L. 2013. Description of five new species and notes on taxonomy of Scathophagidae (Diptera) // Russian Entomological Journal. Vol.22. No.1. P.81-89.

Ozerov A.L., Krivosheina M.G. 2014a. A review of species of the genera Bostrichopyga Becker, 1894 and Paracosmetopus Hackman, 1956 (Diptera, Scathophagidae) // Russian Entomological Journal. Vol.23. No.1. P.85-90.

Ozerov A.L., Krivosheina M.G. 2014b. To the fauna of dung flies (Diptera: Scathophagidae) of Russian Far East // Russian Entomological Journal. Vol.23. No.3. P.203-222.

Ozerov A.L., Krivosheina M.G. 2018. A review of the genus Acanthocnema Becker, 1894 (Diptera: Scathophagidae) of Russia // Russian Entomological Journal. Vol.27. No.1. P.93-100.

Suwa M. 1986. The genus Acanthocnema in Asia and Europe, with description of three new species from Japan and Nepal (Diptera: Scathophagidae) // Insecta Matsumurama, New Series, Vol.34. P.1-33.

Walker F. 1849. List of the specimens of dipterous insects in the collection of the British Museum, London. Vol.4. P.689-1172. 